\title{
THE USE OF SOCIAL NETWORKING TOOL TWITTER TO IMPROVE COLLEGE STUDENTS’ BUSINESS WRITING SKILLS
}

\author{
Lajuan Davis, University of Wisconsin-Whitewater, USA, davisv@uww.edu \\ L. Roger Yin, University of Wisconsin-Whitewater, USA, e-mail: yinl@uww.edu
}

\begin{abstract}
Writing and technology are two skill areas that need to be addressed by educators in the classroom on a constant basis. Employers are searching for employees with appropriate business writing and technology skills. In an effort to satisfy employers' needs, a joining or marrying of the two skills areas needs to be accomplished. Therefore, this study attempts to determine if students' writing skills can be improved by use of the social media tool, Twitter. Since students are already using this social format in their personal lives, integrating it into a business writing class could serve to enhance both students' writing and technology skills.
\end{abstract}

Keywords: social networks; social media; business communication; business writing skills; Twitter

\section{PROBLEM STATEMENT}

How can information technology successfully be married to teaching students the writing skills they need to be employable in the present-day workplace? Since students are already under constant assault by technological text, from television with its scrolling text on news and sports programs to their iPhones spewing text messages, perhaps these same technologies can be utilized as effective pieces of a pedagogical puzzle to help students become more employable. Furthermore, perhaps a social media such as Twitter (defined as a micro-blogging social media that allows users to send messages that are limited to 140 characters), which students are already using sometimes several times a day, can be harnessed to help students improve their writing skills while reinforcing the three concepts of business writing: briefness, clearness, and conciseness.

\section{LITERATURE REVIEW}

"Today's learners face a world in which they will assume new roles as consumers, citizens, and workers. Technology defines these roles very differently today than just 20 [or even two] years earlier" [21]. Technology offers students a window to the world that previous generations of learners could not experience. Author Laurillard states, "There is no point in using communication and information technology unless it clearly improves the quality of learning in some way" [11]. And while studies have been conducted concerning teaching students writing skills and the benefits of teaching with technology $[4,10]$, very little literature exists concerning studies conducted to teach students writing skills using a technological media such as Twitter.

However, what the literature does contain are the numerous accounts of social media, i.e. Twitter, being utilized in business and industry settings. Professional bloggers, J. Blanchard and R. Sullivan, who use Twitter, appreciate the fact that the 140character restriction on writing messages encourages them to be more brief, clear, and concise in their own writing [2, 17]. Surprisingly only an estimated 19\% of Internet users have Twitter accounts [16]. A May 2009 publication of Practical Accountant defines Twitter rules for accountants to use in their daily use of the social network [18]. This Twitter etiquette is expounded upon in the authors' new book ,Twitter Power: How to Dominate Your Market One Tweet at a Time, which again demonstrates the popularity and power of Twitter use. In Entrepreneur journal, author C. Brogan admonishes that using brevity for getting attention and even "getting in front" of the intended audience via tweeting on Twitter is a useful tool for marketing oneself [3]. "Twitter is also a place to keep up with industry news, learn what leaders are doing and thinking about, make new client contacts, and meet and build online relationships with colleagues," says K. O'Moore-Klopf, a freelance medical copyeditor [13]. Other professional writers, M. Deatherage and F. Hughes, agree that Twitter is their virtual "water cooler" that allows them to condense and send a large amount of information to multiple readers at once, from sending health updates to family members to writing and publishing mini-novels for readers everywhere [5, 8]. And Public 
Relations Tactics author A. Wylie (2009) and California Job Journal author S. Dehne (2010) suggest that, "Twitter is the career industry's hottest tool for networking, job hunting and personal branding" [20,6].

In other literature, some educators are "converting to the religion of Twitter" as journalism teacher J. Lanson stated. Lanson admits that using Twitter forces users to write clearly, provides breaking news worldwide, allows individuals to develop networks and distributes information to users quickly and efficiently [9]. American Society for Training and Development editor P. Galagan writes that approximately 700 educators have Twitter accounts as the social media can be considered an "informal information exchange [which] is an adjunct to structured learning events" [7]. Galagan uses Twitter after classes to post questions, assignments, and prompts to students in order to perpetuate learning. By teachers utilizing Twitter appropriately and properly, they can serve as behavior models for students demonstrating writing skills, attributes of professionalism, and networking skills [7]. To reiterate, since students are already using social networks and other technologies in their everyday lives, teaching them to use these technologies appropriately can only be a win-win situation.

Author M. Moody published an article in Spring 2010 that discussed the fact that while social media is changing the world of business and the technological world in general, some educators have not been quick to make curricular changes that reflect the changes in technology. The author admonishes that social media is a powerful tool for "engaging, teaching, and learning in the college classroom ... [that can] enable students to retrieve information and interact with others in real time" [12]. Moody used Twitter in her classroom for students' writing exercises and discussions because Twitter is a micro-blogging service that allows users to communicate with each other and with other individuals outside the classroom environment in real time. Other advantages to using Twitter are that messages can be sent to a group of individuals simultaneously without having to check e-mail in addition to enabling students to follow current events in the news [12].

In a 2009 article written by A. Pennay, the educator infused what he termed techno-literacy into his middle school classroom based on a 2008 study he found published by R. Ramaswami which produced the following results: of the 25 students enrolled in the secondary English course, $74 \%$ perceived that using blog posts assisted them in articulating their ideas more effectively; $68 \%$ perceived that using blogs helped them determine what to say; and $60 \%$ perceived that use of the blogging technology assisted them in organizing, developing, and writing their papers. Pennay concluded his article by reminding educators not to use technology as the teacher but to use technology as a teaching aide. In addition, he restated to readers that regardless of their opinions of social media, students use these media every single day anyway, so integrating its use into the classroom is normally very well accepted by students [15].

In a 2009 article, L. Barack discussed secondary students who were given the task of "Twittering Dante" in a senior English class. Students wrote 140-character tweets (the term used to describe Twitter messages) to engage the writers in composing messages via digital means. This author also emphasized the importance of educators utilizing social media technologies in the classroom to help make existing curricula more relevant and real-time to the students [1]. Additionally, even the primary students are being introduced to social networking systems in the classrooms to engage the "disengaged" students and help them to evaluate and reflect on their own learning [19].

Finally, to demonstrate the power and popularity of Twitter in this country, Twitter was used in a recent court trial in Florida concerning the defendant, C. Anthony, who was accused of the murder of her two year-old child. In preparation for final arguments, Anthony's defense team employed staff members to analyze over 400,000 Twitter and Facebook posts concerning the trial so the defense attorneys could tailor the final argument to fit the crux of public opinion. The defense attorneys' thoughts were that if they addressed popular public opinion in closing arguments, they would then be able to sway the jury members who might also share some of the same public opinion(s). Anthony was acquitted of all charges, not necessarily because of the use of Twitter posts in closing arguments, and this case is an example of the power of social media and the American public's awareness of that power [14].

As is evidenced from the literature review, little or no empirical studies have been conducted to determine if using Twitter in a business writing course can improve students' writing abilities.

In this quasi-experimental design, we are primarily interested in finding whether the use of Twitter in an upper-division Business Communication course can improve college students' business writing skills. Therefore, the hypothesis can be stated as: 
Volume XII, No. 1, pp. 401-406, 2011

$H_{A \text { : }}$ There is a mean grade score difference between Twitter users and non-Twitter users

\section{METHODOLOGY}

Business majors in a medium-sized U.S. Midwest university enrolled in two in-tact, undergraduate traditional business communication courses $(n=68)$ volunteered to participate in this study. These college juniors and seniors taking the upperdivision business communication course are first required to complete three hours of courses in Information Technology to ensure their proficiency with using technology.

The students in each section were given a Perceptions Survey Pretest (a pre-created survey developed and used with the permission of Dr. Dennis LaBonty, 2003) before the project began. The survey consisted of the following statements:

4. I have heard of or am familiar with Twitter.

A Using Twitter in classes is an interesting/valuable concept to me.

A I perceive that I will learn better with Twitter.

A If I were offered the opportunity, I would use Twitter in other classes.

A Taking a course incorporating Twitter is important to me.

The purpose of the pretest was to determine students' perceptions regarding their knowledge and/or use of Twitter before participating in the project. Furthermore, demographic information on the students was obtained and is included in the description portion of this article. At the conclusion of the project, a Perceptions Survey Posttest was administered using the same statements as on the pretest.

The class instructor communicated with students about their participation in the study. Students were told that some of them would be completing various writing assignments via Twitter while others would be using the traditional pencil-and-paper method for submitting assignments. Students were allowed to choose whether they would be using Twitter in the classes by signing a sign-in sheet for the instructor. Students were also permitted to have input as to what topics they would be "tweeting" about, which helped the students feel more involved and empowered in the project process.

All Twitter and all traditional assignments for the two classes were administered and graded by the same instructor. At the conclusion of the semester, students' grades in each of the classes were compared between Twitter users and non-Twitter users to determine if a difference existed between the two groups' grades. Furthermore, information was gathered through qualitative research methods of conducting personal interviews and assessing students' short reflection papers about the Twitter project.

\section{RESULTS}

It was hypothesized that there should be a difference between average final grade points between students who use Twitter for homework and assignments and those who do not use Twitter. Table 1 shows the statistics of mean grades of each of the two groups of 35 students, whereas the Twitter users' 3.662 (approximately an A-) average seems to be in general higher than Non-Twitter users' 3.300571 (approximately an B+). In Figure 1 the boxplot depicts a more widespread grade distribution among Non-Twitter users (1.33 the lowest and 4.00 the highest) comparing to a more concentrated grade distribution of Twitter users (1.33 the lowest and 4.00 the highest ).

Table 2 shows the T-test results of the two sample groups in our study. With a commonly accepted significance level at 0.01 , the P-value at 0.002 is apparently lower than 0.01 . The data collected support the hypothesis that the mean grade scores between Twitter users and Non-Twitter users possess a statistically significant difference.

A preliminary content analysis of the interviews and reflection papers was conducted by the authors shortly after the qualitative data were collected. The general consensus is that the students perceive the use of Twitter whose 140- character per message limit does help their business writing to be more brief, clear, and concise. 
Volume XII, No. 1, pp. 401-406, 2011

\section{CONCLUSIONS \& DISCUSSION}

The findings of this study show that there is a significant difference of average final grades between students who use Twitter for homework and projects and those who do not use Twitter. More specifically, the Twitter users on average receive an A(3.662) as opposed to a B+ (3.300571) average of the Non-Twitter users. This result is encouraging since one professor teaches both sections of the business communication course and grades all writing assignments.

Nonetheless, there are limitations of the current study. First, $n=70$ is not sufficient to generalize the findings reported here. It is planned that the same professor will continue incorporating Twitter in the course in coming semesters so more students' data will be collected in a consistent fashion. Second, since college juniors and seniors have not entered the workforce, they may lack an appreciation of how important high-performance business writing skills can enhance their job functions. The professor has begun teaching an MBA level version of the business communication course with Twitter involvement. It would be interesting to compare the use of Twitter in both undergraduate and graduate-level courses and the quantitative and qualitative data to be collected.

Today's educators, students, and businesspersons are fortunate to have powerful technological tools readily available to them to facilitate the teaching/learning and information-exchange processes. Although Twitter is only one of the social media formats available to technology users, it can be a powerful tool to utilize in the classroom and in office settings. With the 140-character limit on messaging, Twitter fits the way people think and work within the contexts of being brief, clear, and concise in their writing and communication. In addition, the popularity of the use of social media cannot be denied as the number of Twitter and social media users continues to grow.

Moreover, the study conducted for this article is only the tip-of-the-iceberg when contemplating the future implications for using social media as teaching tools. A major factor that requires future study, for example, would be whether the use of these technologies can assist in reducing the anxiety that some individuals feel when faced with completing writing assignments. Because of the present-day generation's comfort level with technologies, harnessing these technologies as teaching methodologies could provide important pieces to the pedagogical and professional puzzles prevalent in the worlds of education and business. Additionally, the numerous professional educators, writers, corporate trainers, and businesspersons who utilize Twitter do suggest that using Twitter improves one's writing. While empirical studies will continue to prove/disprove whether using Twitter in fact develops business writing skills, future studies could also provide evidence that people's writing improves because they are less anxious when writing due to their being comfortable with using technology. In addition to reducing anxiety associated with communication in writing, future studies could point to the fact that using technology could enhance one's motivation to write and thus increase his/her self-efficacy or belief that he/she can succeed at a task. Furthermore, if using Twitter can reduce a writer's anxiety and improve writing skills, what other technologies can be used to further enhance this process?

However, Twitter users need to be appropriately trained, as with any technology tool, to use the social media effectively and efficiently. Users need to become accustomed to formulating their writing with brevity while giving thought to exactly what message needs to be conveyed and how that message needs to be developed, and trainers need to be trained to properly teach Twitter use. When properly educated about Twitter use, educators and users will become empowered and more confident in their writing skills.

\section{REFERENCES}

1. Barack, L. (2009), Twittering Dante, School Library Journal, Retrieved April $5^{\text {th }}$, 2011 from http://www.slj.com

2. Blanchard, J. (2010), How Twitter makes you a better writer, Retrieved January $20^{\text {th }}, 2011$ from http://www.copyblogger.com/twitter-writing

3. Brogan, C. (2011), Brevity rules, Entrepreneur, Retrieved July 1, 2011 from http://www.entreprenuer.com

4. Davis, L. \& Fisher, D. (2009), Teaching with technology to decrease writing apprehension and increase writing skills in a business communication course, Business Education Digest

5. Deatherage, M. (2010), Don't follow me on Twitter, Macworld, 27(3): 104. Retrieved July $7^{\text {th }}$, 2011 from http://web.ebscohost.com

6. Dehne, S. (2010), Think before you tweet, California Job Journal, Retrieved July $7^{\text {th }}, 2011$ from http://web.ebscohost.com 
Volume XII, No. 1, pp. 401-406, 2011

7. Galagan, P. (2009), Twitter as a learning tool. Really., Training and Development, Retrieved July $8^{\text {th }}, 2011$ from http://web.ebscohost.com

8. Hughes, F. (2010), A book Twitter'd, Bookseller, (5420): 15. Retrieved July $7^{\text {th }}$, 2011, from Business Source Premier, http://web.ebscohost.com

9. Lanson, J. (2011), Convert to the religion of Twitter? I'll pass, Christian Science Monitor, Retrieved July $7^{\text {th }}, 2011$ from Academic Search Complete, http://web.ebscohost.com

10. Martinez, C. T., Kock, N. \& Cass, J. (2011), Pain and pleasure in short essay writing: Factors predicting university students' writing anxiety and writing self-efficacy, Journal of Adolescent \& Adult Literacy 54(5): 351-360

11. McKeachie, W.J. (1999), McKeachie's Teaching Tips, $10^{\text {th }}$ ed., Wadsworth, 183-185.

12. Moody, M. (2010). Teaching Twitter and beyond: Tips for incorporating social media in traditional courses. Journal of Magazine \& New Media Research, 11(2), 1-9. Retrieved April 15 ${ }^{\text {th }}, 2011$ from EBSCOhost

13. O'Moore-Klopf, K. (2010), I'm on Twitter-Now what do I use it for? American Medical Writers Association Journal, 25(2): 82-83

14. Pacheco, W. (2011), Social media guided defense in Casey Anthony case, Seattle Times, Retrieved July $14^{\text {th }}$, 2011 from $\mathrm{http}: / /$ seattletimes.nwsource.com/html/nationworld/2015603216_anthonytrial14.html

15. Pennay, A. (2009), Techno-literacy: A boon for writing instruction in the classroom. California English, 15.1, 18-20. Retrieved March $30^{\text {th }}, 2011$ from EBSCOhost

16. Twitter and status updating, fall 2009, Pew Internet, Retrieved July $14^{\text {th }}, 2011$ from http://www.pewinternet.org/Reports/2009/17-Twitter-and-Status-Updating-Fall-2009.aspx

17. Sullivan, R. (2009), Can Twitter improve writing? Retrieved January $20^{\text {th }}, 2011$ from http://www.redsquareagency.com/blog/twitter-improve-writing

18. Twitter rules, (2009), Practical Accountant Tech Bulletin, Retrieved July $7^{\text {th }}, 2011$ from EBSCOhost at http://discombobulate.com

19. Waller, M. (2010), 'It's very very fun and ecsiting — using Twitter in the primary classroom, English, Four to eleven, Retrieved March $15^{\text {th }}, 2011$ from EBSCOhost

20. Wylie, A. (2009), Tweak your tweets: How to contribute to the conversation in 140 characters or less, Public Relations Tactics, Retrieved July 1st, 2011 from EBSCOhost at http://web.ebscohost.com

21. Zeliff, N. (2004), Pedagogical and technological challenges of the Internet. National Business Education Association 2004 Yearbook. Reston, VA, 67 
Volume XII, No. 1, pp. 401-406, 2011

Table 1 - Summary Statistics for Grades

\begin{tabular}{|c|c|c|c|c|c|r|r|r|r|r|r|}
\hline Twitter & $\mathbf{n}$ & Mean & Variance & Std. Dev. & Std. Err. & Median & Range & Min & Max & Q1 & Q3 \\
\hline Non-Twitter Users & 35 & 3.300571 & 0.3880702 & 0.6229529 & 0.10529825 & 3.33 & 2.67 & 1.33 & 4 & 3 & 3.66 \\
\hline Twitter Users & 35 & 3.662 & 0.0526223 & 0.2293956 & 0.03877493 & 3.66 & 1 & 3 & 4 & 3.66 & 3.66 \\
\hline
\end{tabular}

Figure 1 - Boxplot of Grades of Twitter and Non-Twitter Users

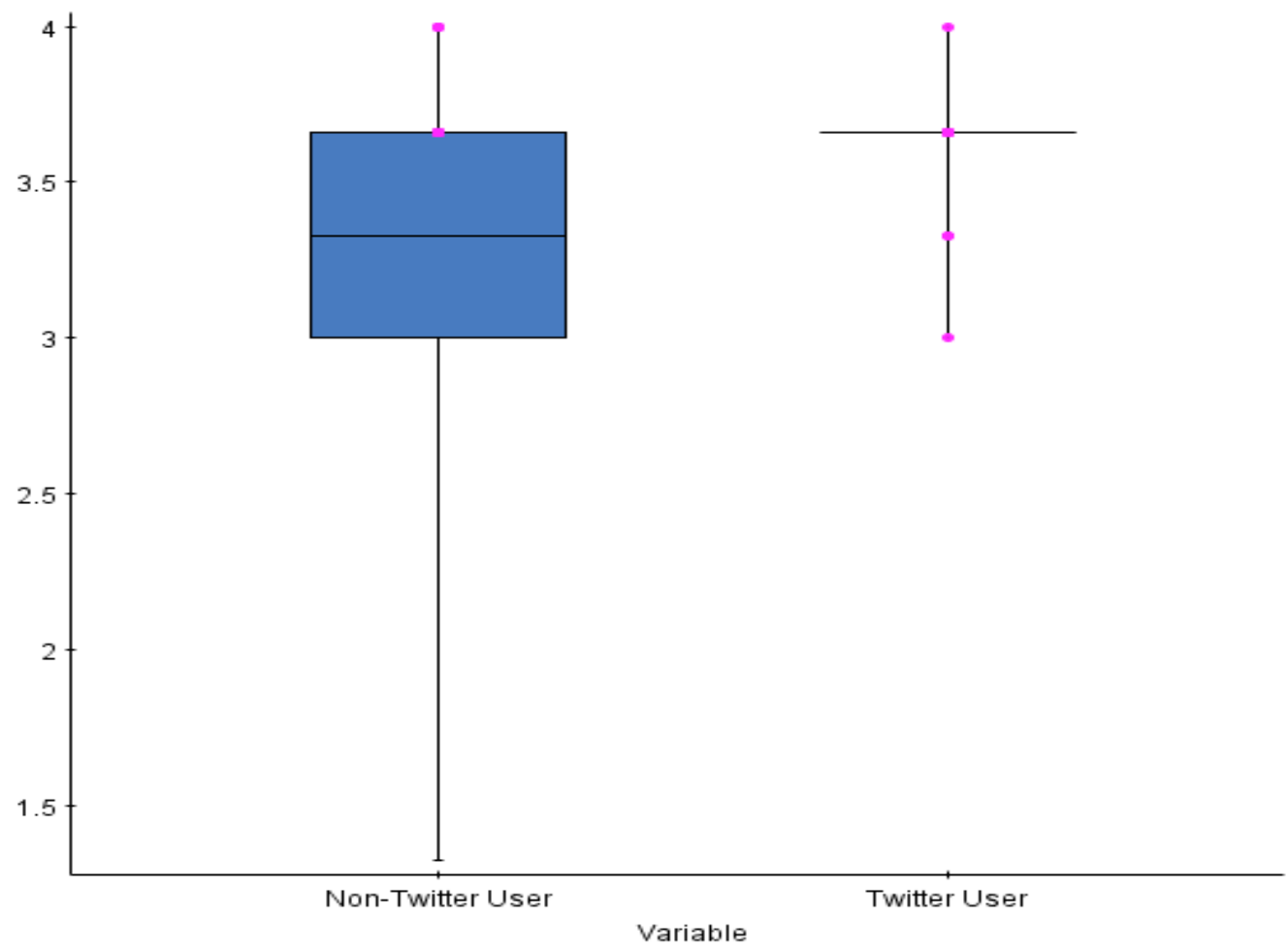

Table 2 - T statistics with Grades of Twitter and Non-Twitter Users

\begin{tabular}{|c|c|c|c|c|r|}
\hline Difference & $\begin{array}{c}\text { Sample } \\
\text { Mean }\end{array}$ & Std. Err. & DF & T-Stat & P-value \\
\hline$\mu_{1}-\mu_{2}$ & -0.36142856 & 0.11221059 & 68 & -3.220984 & 0.002 \\
\hline
\end{tabular}

$\mu_{1}$ : mean of Non-Twitter User

$\mu_{2}$ : mean of Twitter User

$\mu_{1}-\mu_{2}:$ mean difference

$\mathrm{H}_{0}: \mu_{1}-\mu_{2}=0$

$\mathrm{H}_{\mathrm{A}}: \mu_{1}-\mu_{2} \neq 0$ 